\title{
Influence of Different Tillage Systems on Soybean Nodulation and Yield in the Transylvanian Plain Conditions
}

\author{
Felicia CHEŢAN ${ }^{1^{*}}$ \\ ${ }^{1}$ Agricultural Research and Development Station, Turda, 27 Agriculturii Street, Cluj County, Romania \\ *corresponding author: felice_fely@yahoo.com
}

Bulletin UASVM series Agriculture 77(2) / 2020

Print ISSN 1843-5246; Electronic ISSN 1843-5386

DOI:10.15835/buasvmcn-agr: 2020.0039

\begin{abstract}
The paper presents the results of research conducted during 2018-2019, regarding the root nodules formation at soybean, by applying different tillage systems, under the conditions of the Agricultural Research and Development Station Turda situated in the Transylvanian Plain.The development of root nodules in soybean differs from one variety to another, the highest value of 103 nodules/plant is recorded in the Onix variety and lower in the Cristina and Felix variety with 66 and 69 nodules respectively. Also at the weight of the nodules/plant it seems to maintain the same trend, the Onix variety $(0.86 \mathrm{~g})$ being superior to the other two varieties (Felix $0.83 \mathrm{~g}$, Cristina $0.80 \mathrm{~g}$ ). The highest soybean average yield was registered at the Cristina variety cultivated in the minimum tillagechisel (2548 kg/ha) and the lowest yield at the Felix variety in the no tillage $(1592 \mathrm{~kg} / \mathrm{ha})$.
\end{abstract}

Keywords: soybean, root nodules, tillage system, yield

\section{INTRODUCTION}

The particular importance of soybean comes from its multiple usages both in the alimentation of people (oil, the mature beans and the green hulls are used in various food recipes), (Subramanian and Smith, 2013; Cvijanovic and Cvijanovic, 1988) and in the feeding of animals as well as in industry (oils for painting, the production of plastic mass, the preparation of margarine), and it is also used in the regeneration of the physical properties of the soil due to the symbiosis which is installed between the radicular system and the Bradyrhizobium japonicum bacteria, this symbiosis resulting in the development of special formations (nodules) for the function of fixing atmospheric nitrogen for the benefit of the plant (Roman et al., 2006; Stevanović et al., 2016; Popović et al., 2016, 2018). Keyser and Li (1992) mentions that "the soybean-Bradyrhizobium symbiosis can fix about $300 \mathrm{~kg} \mathrm{~N} \mathrm{ha}{ }^{-1}$ under good conditions".
Nitrogen fixation begins (in optimal conditions) after soybean emergence every 2-3 weeks, doubling the amount of nitrogen fixed every 6-10 days (Hinson and Hartwig, 1978). It is known that soil acidity $(\mathrm{pH})$ affects nitrogen fixation, a $\mathrm{pH}$ of less than 6.0 decreases the production and number of root nodules of legumes (Muntean et al., 1995; Scurtu, 2001; Guș et al., 2004; Vidican et al., 2013). If there are colonies of Rhizobium in the soil, that cause the formation of nodules on the roots of the silk, plants are able to use atmospheric nitrogen, usually unable to fully secure their atmospheric nitrogen, therefore some must be obtained from the soil (through applied mineral fertilizers). Of the total nitrogen needed for soybeans, $70 \%$ are provided symbiotically (Vidican et al., 2013; Li et al., 2020). After the soy crop, the need for nitrogen fertilizers is greatly reduced, and against the background of this culture increases the efficiency of phosphate and potash fertilizers with an eco- 
nomic and agrotechnical efficiency (Höflich et al., 1999; Peoples et al., 2009; Cheţan and Cheţan, 2013; Chețan et al., 2016; Şimon et al., 2017).

The paper presents the results of research conducted during 2018-2019, regarding the root nodules formation at soybean, by applying different tillage systems, under the conditions of the Agricultural Research and Development Station Turda situated in the Transylvanian Plain.

\section{MATERIALS AND METHODS}

Field experiments were conducted during two years $(2018,2019)$ at ARDS Turda, located at $23^{\circ} 47^{\prime}$ longitude and $46^{\circ} 35^{\prime}$ latitude on $345-493 \mathrm{~m}$ altitude, in West of the Transylvanian Plain, Turda town. The experimental field was placed on a Phaeozem argic soil type (SRTS, 2012), having the following properties (MESP, 1987): neutral pH; good and very good supply with mobile phosphorus (over $4.5 \% \mathrm{mg} \mathrm{P}_{2} \mathrm{O}_{5} / 100 \mathrm{~g}$ soil) and potassium (over $30 \mathrm{mg} \mathrm{K}_{2} \mathrm{O} / 100 \mathrm{~g}$ soil); the content in humus is average $(3.5 \%)$. The experiment being included in a crop rotation of 3 years: maize-soybean autumn wheat. The biological material chosen for this trial was represented by the soybean Onix, Felix and Cristina varieties.

The experimental factors were the following: factor $\mathbf{A}$ - soybean variety with three graduations: $a_{1}$ - Onix; $a_{2}$ - Felix; $a_{3}$ - Cristina; factor $\mathbf{B}$ - tillage system with four graduations: $b_{1}$ - classic with plow (CS), $b_{2}$ - minimum tillage with chisel (MC), $\mathrm{b}_{3}$ - minimum tillage with heavy disc (MD), $\mathrm{b}_{4}-$ no tillage-direct sowing (NT); factor C - agricultural year with two graduations: $c_{1}-2018, c_{2}-2019$.

The technology for each system in the experiment was performed according to the experimental plan:

- CS: plowing to $30 \mathrm{~cm}$ depth + disk + rotary harrow + sowing simultaneously with the fertilization + herbicide pre-emergent + postemergent herbicide + pest control treatment + harvested by chopping and spreading plant debris to the soil surface;

- MC: scarified to a depth of $30 \mathrm{~cm}$ rotary harrow + sowing simultaneously with the fertilization + pre-emergent herbicide + post-emergent herbicide + pest control treatment + harvested by chopping and spreading plant debris to the soil surface;

- MD: disked at $12 \mathrm{~cm}$ depth + rotary harrow + sowing simultaneously with the fertilization
+ pre-emergent herbicide + post-emergent herbicide + pest control treatment + harvested by chopping and spreading plant debris to the soil surface;

- NT: direct sowing, simultaneously with the fertilization + pre-emergent herbicide + postemergent herbicide + pest control treatment + harvested by chopping and spreading plant debris to the soil surface.

The sowing was done with the Directa- 400 machine (at the same time as sowing was applied the fertilizer $\mathrm{N}_{40} \mathrm{P}_{40} \mathrm{~K}_{0}$ a.c/ha, avoiding repeated crossings with heavy aggregates on the soil surface), at $18 \mathrm{~cm}$ distance between the rows, the seed introduced at $4 \mathrm{~cm}$ depth, density $65 \mathrm{~g} . \mathrm{g} . / \mathrm{m}^{2}$.

Weeds control was carried out in two stages, in all variants: pre-emergence with $0.35 \mathrm{l} / \mathrm{ha}$ produced on the basis of metribuzin $(600 \mathrm{~g} / \mathrm{l})+$ $1.5 \mathrm{l} /$ ha produced on the basis of $S$ - metolachlor (960 g/l); post-emergence with $1.0 \mathrm{l} / \mathrm{ha}$ based on imazamox $(40 \mathrm{~g} / \mathrm{l})+1.0 \mathrm{l} / \mathrm{ha}$ based on propaquizafop $(100 \mathrm{~g} / \mathrm{l})$, in soybean phase 3-4 trifoliate leaves, dicotyledonous weeds in 2- 4 leaves and monocotyledonous weeds were not twinned. To control the pest Tetranicus urticae, at the time of reporting, treatment with $0.5 \mathrm{l} / \mathrm{ha}$ insecticide based on fenpyroximate was performed. After the soybean harvesting the yield obtained was corrected to $13 \%$ moisture content.

The determination of root nodules were made at the blooming, in each experimental variant, on an area of $0.25 \mathrm{~m}^{2}$ (the metric frame), with a spade, without damaging the roots, the soy plants was extracted together with the volume of soil explored by the root system, from each variant and the nodules counted. The results obtained were statistically processed according to the method of analyzing the variant and establishing the lowest significant differences, $\operatorname{LSD}(5 \%, 1 \%$ and $0.1 \%)$ (ANOVA, 2015).

The evolution of the thermal and rainfall regime at ARDS Turda (Meteorological Station Turda, longitude: $23^{\circ} 47^{\prime}$; latitude $46^{\circ} 35^{\prime}$; altitude $427 \mathrm{~m}$ ) for the last 63 years (1957-2019) is presented in Figure 1.

\section{RESULTS AND DISCUSSION}

In the 63 years since the evolution of climatic conditions in Turda was monitored, from the data collected at Turda Meteorological Station (1957- 
2019), a warming process was observed which felt more pronounced after 2007 (Figure 1).

The multiannual average for 63 years was $9.2^{\circ} \mathrm{C}$, the number of years in which the average annual temperature was below $9^{\circ} \mathrm{C}$ was 25 years, 25 years with a temperature of $9^{\circ} \mathrm{C}$ and above $9^{\circ} \mathrm{C}$ and 13 years in which average annual values of temperatures above $10^{\circ} \mathrm{C}$, especially in recent years (2015-2019). The highest values of average annual temperature are attributed to the year $2019\left(11.4^{\circ} \mathrm{C}\right)$ and the lowest temperature to the 1975 year $\left(7.4^{\circ} \mathrm{C}\right)$.

The evolution of the rainfall regime was uneven and no dominant trend was observed, the multiannual amount for 63 years was $531.4 \mathrm{~mm}$, the number of years in which the precipitations had values below $500 \mathrm{~mm}$ was 24 years, over 500 $\mathrm{mm}$ in 22 years, over $600 \mathrm{~mm}$ were recorded in 13 years and in four years the precipitations had values over $700 \mathrm{~mm}$. The highest rainfall in the entire period was recorded in 2016 with 816.8 $\mathrm{mm}$ and the lowest rainfall was recorded in 2000 (259.7 mm).

The registered climatic changes (increasing temperatures, decrease in rainfall or nonuniformity of rainfall), as well as the unpredictable ones in the future require the judicious choice of the biological material to be cultivated and the application of some technologies adequate to the new climatic conditions, that why the applied agrotechnical measures must be adapted to more oscillating ecological conditions.

Specific to the two years studied $(2018,2019)$, was the uneven distribution of precipitation, there were dry periods of time, with prolonged pedological droughts followed by torrential rains. The average values of temperature and rainfall, recorded during the experimentation period, were the basis for the climatic characterization of the years (Table 1).

The development of root nodules at soybean differs from one variety to another, from the data presented in Table 2, one can observe the significantly negative influence of the varieties Felix and Cristina in the formation of nodules. The highest value of 103 nodules/plant is recorded at the Onix variety (witness) and lower at the Cristina and Felix variety with 66 and 69 nodules. Also at the weight of the nodules/plant it seems to maintain the same trend, the Onix variety $(0.86$ g) being superior to the other two varieties (Felix $0.83 \mathrm{~g}$, Cristina $0.80 \mathrm{~g}$ ), but the differences do not present the statistical insurance.

The difference between the four systems of work in the study, suggests to us that soybean has no great preferences over the system factor of the

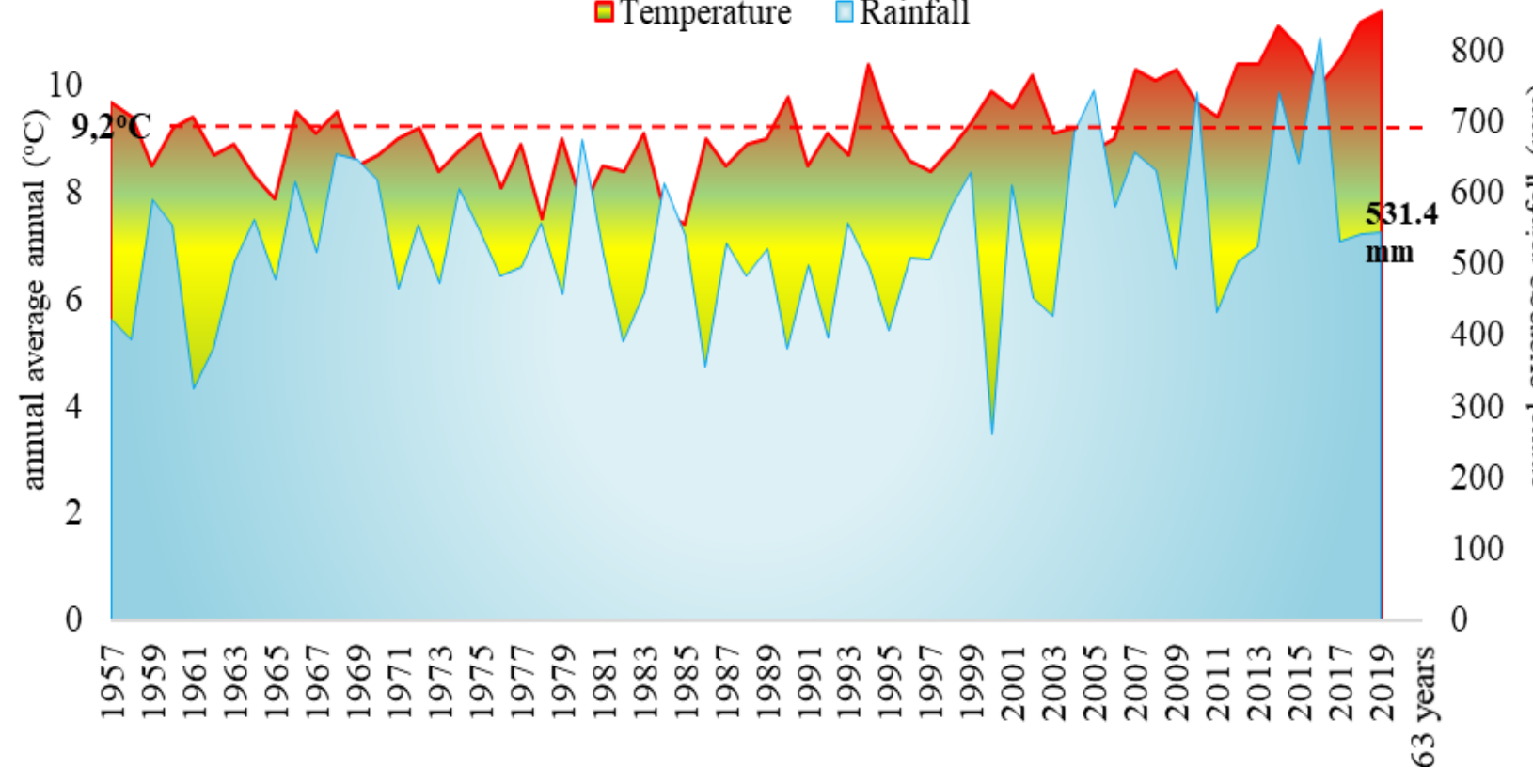

Figure 1. The evolution of the thermal and rainfall regime at ARDS Turda (1957-2019) 
Table 1. Climatic characterization of the experiment years 2018-2019 in terms of deviation from the multiannual average over 63 years (1957-2019), ARDS Turda

\begin{tabular}{|c|c|c|c|c|c|c|c|}
\hline \multirow{3}{*}{ No. } & \multirow{3}{*}{ Month } & \multicolumn{2}{|c|}{$\begin{array}{l}\text { Average/sum } \\
63 \text { years }\end{array}$} & \multicolumn{4}{|c|}{ Year/deviation \pm multiannual average/sum } \\
\hline & & \multirow[b]{2}{*}{${ }^{\circ} \mathrm{C}$} & \multirow[b]{2}{*}{$\mathbf{m m}$} & \multicolumn{2}{|c|}{2018} & \multicolumn{2}{|c|}{2019} \\
\hline & & & & ${ }^{\circ} \mathrm{C}$ & $\mathbf{m m}$ & ${ }^{\circ} \mathrm{C}$ & $\mathbf{m m}$ \\
\hline 1 & I & -3.3 & 21.8 & +3.5 & -5.1 & +1.1 & +24.2 \\
\hline 2 & II & -0.7 & 19.0 & +0.4 & +14.4 & +2.4 & -4.3 \\
\hline 3 & III & 4.4 & 24.1 & -1.1 & +16.8 & +2.9 & -11.8 \\
\hline 4 & IV & 10.0 & 46.2 & +5.3 & -20.0 & +1.3 & +16.4 \\
\hline 5 & $\mathrm{~V}$ & 15.0 & 69.6 & +3.7 & -12.8 & -1.4 & +82.8 \\
\hline 6 & VI & 18.0 & 83.9 & +1.4 & +14.4 & +3.8 & -15.1 \\
\hline 7 & VII & 19.8 & 77.1 & +0.6 & +8.6 & +0.6 & -42.1 \\
\hline 8 & VIII & 19.5 & 56.1 & +2.8 & -17.9 & +2.6 & +7.7 \\
\hline 9 & IX & 15.1 & 42.2 & +1.6 & -12.4 & +2.0 & -22.8 \\
\hline 10 & $\mathrm{X}$ & 9.8 & 35.5 & +2.9 & -8.7 & +3.7 & -9.9 \\
\hline 11 & $\mathrm{XI}$ & 4.0 & 28.5 & +2.0 & +1.1 & +4.9 & -0.1 \\
\hline 12 & XII & -1.3 & 27.3 & +0.4 & +31.0 & +2.2 & -131 \\
\hline \multicolumn{2}{|c|}{ Average } & 9.2 & 531.4 & 11.2 & 540.7 & 11.4 & 543.2 \\
\hline \multicolumn{2}{|c|}{ Deviation \pm 63 years } & $*$ & $*$ & +2.0 & +9.3 & +2.2 & +11.8 \\
\hline \multicolumn{2}{|c|}{ Characterization } & $*$ & $*$ & warm & normal & warm & norma \\
\hline
\end{tabular}

work with soil mobilization and lends itself less to the NT that distinctly significantly influences the formation of nodules. In this variant recording the lowest number (64 nodules) compared to the MC (73 nodules) and the MD (70 nodules) whose values were closer to the control (CS with 82 nodules) the differences between 9-12 nodules present the statistical insurance (significantly negative).

In terms of the weight of the formed nodules, the beneficial effect of the MC is found in the difference of only $0.03 \%$, compared to the control variant (CS) at which the formed nodules had a weight of $0.89 \mathrm{~g} /$ plant, this difference does not present statistical assurance. The contrary results were obtained by Dogan et al., (2011) following experiments performed in the Cukurova Region in Turkey, they states that the highest average number of nodules was obtained in the no tillage system with sowing directly in the wheat stubble and a smaller number (56 nodules) in the field with mobilization of the soil at $18-20 \mathrm{~cm}$. And from other research (Chețan et al., 2015) results the favorable influence of the CS system in the development of the roots of silk that explores a well-made and airy soil, the most root nodules (over $90 \%$ ) it found in the first $30 \mathrm{~cm}$ of soil.

In the MD (0.78 g) and NT (0.63 g) the same downward trend is maintained in terms of the weight of the formed nodules, with distinct and very significant negative influence. Referring to the average of the two years considered control $(0.79$ nodules), the root nodules to soybean is influenced more by the year factor (climate conditions). The drought in the spring of 2018 during the sowing period and in the period immediately following sowing caused a staggered increase in the variety, which led to a poor development of soybean culture with a distinctly significantly negative influence both in the number (63 nodules) but also in the weight of the nodules $(0.58 \mathrm{~g})$. The rains in April and May 2019 ensured a good start 
for soybeans (the emergence and the uniform development) which significantly influenced the formation of nodules ( 96 nodules by weight of 1.08 g), differences from the control (79 nodules with 0.83 g). Peoples et al., (2009) and Stevanović et al., (2017) state that high temperatures, humidity, degree of diseases and pest attack quantitatively influence the fixation of nitrogen in the soil, also the efficiency of Rhizobium batteries is limited if chemical fertilizers based on nitrogen are applied in high doses and the excessive soil tillage. Other studies conducted in the area of Moldova confirm that the lack of water causes poor development of soy culture that can't support the growth and development of root nodules making it difficult to fix nitrogen (www.donausoja.org).

As can be seen from Table 3, of all three varieties chosen in the experiment, at the Onix variety the number of nodules formed were the highest in all tillage systems (around 100), this fact is reflects on yield in the CS $(2411 \mathrm{~kg} / \mathrm{ha})$ and MC $(2450 \mathrm{~kg} /$ ha) and less in the MD (2123 kg/ha) and NT (1819 $\mathrm{kg} / \mathrm{ha}$ ).

Compared to the CS variant $(2354 \mathrm{~kg} / \mathrm{ha}$ and 77 nodules), the Felix variety adapted very well to the minimum technology (MC and MD), the yield made in these systems was $2431 \mathrm{~kg} / \mathrm{ha}$ and 2218 $\mathrm{kg} / \mathrm{ha}$, although in these variants the number of nodules was reduced $(60,65)$. It seems that the Felix variety is pretentious compared to the NT system, achieving the lowest average grain yield $(1592 \mathrm{~kg} / \mathrm{ha})$ of all the experimental variants and as the number of nodules it registered almost the same value as in the others systems.

The Cristina variety is the least pretentious compared to the unconventional technology, in

Table 2. The influence of the experimental factors on root nodules formation (2018-2019)

\begin{tabular}{|c|c|c|c|c|c|c|c|}
\hline \multirow{2}{*}{\multicolumn{2}{|c|}{$\begin{array}{c}\text { The factor } \\
\text { Variety (A) }\end{array}$}} & \multicolumn{6}{|c|}{ Blooming - soybean phase } \\
\hline & & \multirow{2}{*}{$\begin{array}{c}\text { no. nod./pl } \\
103 \\
\end{array}$} & \multirow{2}{*}{$\begin{array}{c}\% \\
100 \\
\end{array}$} & \multirow{2}{*}{$\begin{array}{c}\text { Difference } \\
\mathbf{0 . 0 0}^{\mathrm{wt}} \\
\end{array}$} & \multirow{2}{*}{$\begin{array}{c}\text { weight nod/pl/g } \\
0.86 \\
\end{array}$} & \multirow{2}{*}{$\begin{array}{c}\% \\
100 \\
\end{array}$} & \multirow{2}{*}{$\begin{array}{c}\text { Difference } \\
\mathbf{0 . 0 0}^{\mathrm{wt}} \\
\end{array}$} \\
\hline$a_{1}$ & Onix & & & & & & \\
\hline$a_{2}$ & Felix & 69 & 67 & $-34^{\circ 0}$ & 0.83 & 97 & -0.03 \\
\hline$a_{3}$ & Cristina & 66 & 65 & $-36^{\circ 0}$ & 0.80 & 93 & $-0.06^{-}$ \\
\hline & LSD (p 5\%) & & & 9 & & & 0.09 \\
\hline & LSD (p 1\%) & & & 22 & & & 0.22 \\
\hline & LSD (p 0.1\%) & & & 69 & & & 0.69 \\
\hline & Tillage system (B) & no. nod./pl & $\%$ & Difference & weight nod/pl/g & $\%$ & Difference \\
\hline $\mathrm{b}_{1}$ & Classic (CS) & 82 & 100 & $0.00^{\mathrm{wt}}$ & 0.89 & 100 & $0.00^{\mathrm{wt}}$ \\
\hline $\mathrm{b}_{2}$ & Minim chisel (MC) & 73 & 89 & $-9^{\circ}$ & 0.92 & 103 & $0.03^{-}$ \\
\hline $\mathrm{b}_{3}$ & Minim disk (MD) & 70 & 85 & $-12^{\circ}$ & 0.78 & 88 & $-0.11^{\circ 0}$ \\
\hline $\mathrm{b}_{4}$ & No tillage (NT) & 64 & 78 & $-18^{\circ 0}$ & 0.63 & 71 & $-0.26^{000}$ \\
\hline & LSD (p 5\%) & & & 6 & & & 0.05 \\
\hline & LSD (p 1\%) & & & 8 & & & 0.08 \\
\hline & LSD (p 0.1\%) & & & 13 & & & 0.12 \\
\hline & Year (C) & no. nod./pl & $\%$ & Difference & weight nod/pl/g & $\%$ & Difference \\
\hline $\mathrm{c}_{0}$ & Average & 79 & 100 & $0.00^{\mathrm{wt}}$ & 0.83 & 100 & $0.00^{\mathrm{wt}}$ \\
\hline $\mathrm{c}_{1}$ & 2018 & 63 & 80 & $-16^{\circ 0}$ & 0.58 & 70 & $-0.25^{000}$ \\
\hline $\mathrm{c}_{2}$ & 2019 & 96 & 120 & $16^{* *}$ & 1.08 & 130 & $0.25^{* * *}$ \\
\hline & LSD (p 5\%) & & & 5 & & & 0.06 \\
\hline & LSD (p 1\%) & & & 7 & & & 0.09 \\
\hline & LSD (p 0.1\%) & & & 10 & & & 0.14 \\
\hline
\end{tabular}


Table 3. The influence of the tillage systems on nodules number and the soybean yield (2018-2019)

\begin{tabular}{lcccccc}
\hline Tillage system x variety & no. nod./pl & $\mathbf{\%}$ & Difference & Yield kg/ha & \% & Difference \\
\hline CS Onix & 106 & 100 & $0.00^{\text {wt }}$ & 2411 & 100 & $0.00^{\text {wt }}$ \\
\hline MC Onix & 100 & 94 & $-6^{-}$ & 2450 & 102 & $39^{-}$ \\
\hline MD Onix & 98 & 93 & $-8^{\circ}$ & 2123 & 88 & $-288^{\circ}$ \\
\hline NT Onix & 103 & 97 & $-3^{-}$ & 1819 & 75 & $-592^{\text {oo }}$ \\
\hline CS Felix & 77 & 100 & $0.00^{\text {wt }}$ & 2354 & 100 & $0.00^{\text {wt }}$ \\
\hline MC Felix & 60 & 78 & $-17^{\text {ooo }}$ & 2431 & 103 & $77^{-}$ \\
\hline MD Felix & 65 & 84 & $-1^{\text {oo }}$ & 2218 & 94 & $-136^{-}$ \\
\hline NT Felix & 70 & 91 & $-7^{-}$ & 1592 & 68 & $-762^{\text {ooo }}$ \\
\hline CS Cristina & 62 & 100 & $0.00^{\text {wt }}$ & 2485 & 100 & $0.00^{\text {wt }}$ \\
\hline MC Cristina & 61 & 98 & $-1^{-}$ & 2548 & 103 & $63^{-}$ \\
\hline MD Cristina & 58 & 94 & -4 & 2165 & 87 & $-320^{\circ}$ \\
\hline NT Cristina & 76 & 123 & $14^{* *}$ & 2001 & 81 & $-484^{\circ}$ \\
\hline LSD (p 5\%) & 7 & & & 372 & & \\
LSD (p 1\%) & 10 & & & 534 & & \\
LSD (p 0.1\%) & 15 & & & 786 & & \\
\hline
\end{tabular}

all four variants of tillage the yield were superior to the other varieties although the number of nodules was quite low (58-76), but the average yield achieved in the variant NT $(2001 \mathrm{~kg} / \mathrm{ha}$ and 76 nodules), therefore in the future this variety must be taken into account when applying unconventional technology. From the research conducted by Căpățână et al., (2018), regarding the influence of soil tillage on soybean nodulation and yield, the experiment was placed on a chromic luvisol with a clay-loam texture, located at Moara Domnească - Ilfov, results that the number of nodules/plant recorded in the plowing at $20 \mathrm{~cm}$ ( 23.8 nodules; the yield $2351 \mathrm{~kg} / \mathrm{ha}$ ), the highest value obtained in chisel plow at $20 \mathrm{~cm}(27.0$ nodules; the yield $2260.7 \mathrm{~kg} / \mathrm{ha}$ ) and the lower values in disking at $10 \mathrm{~cm}$ (22.9 nodules; the yield $2044 \mathrm{~kg} / \mathrm{ha}$ ). Regarding the beneficial influence of the classical system on soybean yield, similar results were obtained in Poland by Gawęda et al., (2020), which showed that the yield was higher by $10.3 \%$ in the classic system (plowing), compared with no tillage system.

The experiment at ARDS Turda was conducted on fertile soil but also with susceptibility to rapid compaction when passing large agricultural aggregates, or when working mechanically in conditions of high humidity, the soil moisture of $24-25 \%$ is high enough to produce a surface compaction. The land on which the experiment was set up has a high clay content (more than $40 \%$ ). The climatic conditions during the experimentation period were less favorable in expressing the yield potential of the soybean varieties studied and in the yield it seems that a very important role together with the technological elements is mineral fertilization with $\mathrm{N}_{40} \mathrm{P}_{40}$ (applied simultaneously with sowing) providing the plants with the necessary nitrogen in addition to nitrogen from the air symbiotically fixed by Rhizobium bacteria in the root nodules.

\section{CONCLUSION}

The highest value of 103 nodules/plant is recorded at the Onix variety and lower at the Cristina (66 nodules) and Felix (69 nodules).

The weight of the nodules was superior at Onix variety $(0.86 \mathrm{~g})$ to the other two varieties (Felix $0.83 \mathrm{~g}$, Cristina $0.80 \mathrm{~g}$ ).

In the formation of root nodules, a major role belongs to the climatic conditions, the reduced precipitations from April-May of 2018, corroborated with high temperatures that persisted for a long period of time, led to the poor development 
at culture with a distinctly significantly negative influence both in the number but also in the weight of the nodules.

The Cristina variety is the least pretentious in terms of a the system applied, in all four tillage systems the yield were higher than at the other varieties, although the number of nodules was quite low (58-76 nodules), the noting in specially the yield achieved in the NT system $(2001 \mathrm{~kg} / \mathrm{ha}$ and 76 nodules).

The highest soybean average yield was registered at the Cristina variety cultivated in the MC $(2548 \mathrm{~kg} / \mathrm{ha})$ and the lowest yield at the Felix variety in the NT (1592 kg/ha).

The minor difference of $39 \mathrm{~kg} / \mathrm{ha}$ between the yield obtained for the Onix variety, $2411 \mathrm{~kg} / \mathrm{ha}$ in SC and $2450 \mathrm{~kg} / \mathrm{ha}$ in MC, suggests the suitability of cultivation in this system as well.

In the climate and soil conditions in the study area, soybean cultivation in the MC is suitable as an alternative to the CS.

Acknowledgements. This work was supported by a grant of the Romanian Ministry of Research and Innovation, CCCDI- UEFISCDI, PN-III-P1-1.2PCCDI-2017-0056, within PNCDI III.

\section{REFERENCES}

1. Căpățână N, Bolohan C, Oprea CA, Marin DI (2018). Influence of soil tillage systems and inoculation on soybean nodulation and yield. Scientific Papers. Series A. Agronomy, 61(1): 46-52.

2. Chețan C, Rusu T, Chețan F, Şimon A (2015). Research regarding the influence weed control treatments on production and qualitative indicators soybean cultivated in minimum tillage system. Bulletin USAMV Agriculture, 73(2): 170-175.

3. Chețan F, Chețan C (2013). Soybean cultivation in the conservative farming system and its role in protecting the environment. Volume CIEC National Symposium "Use of mineral and organo-mineral fertilizers in agriculture" Scientific Papers, Bucharest, AGRIS Publishing House Agricultural magazines SRL, Bucharest.

4. Chețan F, Chețan C, Mureșanu F (2016). Determining the technology influence of soy on the soil, production and economic efficiency on Turda area. International Symposium "Agricultural Economics and Rural Development - Realities and perspectives for Romania", $7^{\text {th }}$ edition, ASE Publishing, Bucharest.

5. Cvijanovic D, Cvijanović G (1988). Display and assessment of the dynamic development of production and consumption of soybean in the world. Economics of agricultural, 35 (11-12): 687-697.
6. Dogan K, Celik I, Gok M, Coskan A (2011). Effect of different soil tillage methods on rhizobia nodulation, biomass and nitrogen content of second crop soybean. African Journal of Microbiology Research, 5(20) 3186-3194.

7. Gawęda D, Nowak A, Haliniarz M, Woźniak A. (2020). Yield and Economic Effectiveness of Soybean Grown Under Different Cropping Systems. International Journal of Plant production, 14: 475-485.

8. Guş P, Cernea S, Rusu T, Bogdan I (2004). Systems of seeding, fertilizing and conservating the crops. ClujNapoca: Risoprint Publishing House, p. 220.

9. Hinson K, Hartwig E (1978). La culture de soja sous les tropiques. FAO, Roma.

10. Höflich G, Tauschke M, Kühn G, Werner K, Frielinghaus M, Höhn W (199). Influence of long-term conservation tillage on soil and rhizosphere microorganisms. Biology and fertility of soils, 29(1): 81-86.

11. Keyser HH, Li F (1992). Potential for increasing biological nitrogen fixation in soybean. Plant Soil 141: 119-135.

12. Li R, Chen H, Yang Z, Yuan S, Zhou H (2020). Research status of soybean symbiosis nitrogen fixation. Oil Crop Science 5: 6-10.

13. Muntean LS, Axinte M, Borcean I, Roman G (1995). Phytotechnics. EDP, București.

14. Peoples MB, Brockwell J, Herridge DF, Rochester IJ, Alves BJR, Urquiaga S, Boddey RM, Dakora FD, Bhattarai S, Maskey SL, Sampet C, Rerkasem B, Khan DF, HauggaardNielsen H, Jensen ES (2009). The contributions of nitrogen-fixing crop legumes to the productivity of agricultural systems. Symbiosis, 48: 1-17.

15. Popovic V, Tatic M, Sikora V, Ikanovic J, Drazic G, Djukic V, Mihailovic B, Filipovic V, Dozet, G, Jovanovic Lj, Stevanovic $P$ (2016). Variability of yield and chemical composition in soybean genotypes grown under different agroecological conditions of Serbia. Romanian Agricultural Research, 33: 29-39.

16. Popović V, Živanović Lj, Kolarić Lj, Ikanović J, Simić D, Tatić $\mathrm{M}$, Stevanovic $\mathrm{P}$ (2018). Effect of nitrogen fertilization on the yield components of soybean (Glycine max (L.) Merr). Journal of Institute of PKB Agroekonomik, Belgrade, 24(12): 101-110.

17. Roman GV, Ion V, Epure LI (2006). Phytotechnics- Cereal grains and legumes. Editura Ceres, Bucureşti.

18. Scurtu I (2001). Economics and technology of agricultural crops. Pitesti: Economic Independence Publishing House, p. 231-236.

19. Subramanian S, Smith DLA (2013). A proteomics approach to study soybean and its symbiont Bradyrhizobium japonicum-a review. INTECH Open Access Publisher 3-30.

20. Șimon A, Chețan F, Chețan C, Deac V (2017). Research on the influence of the soil tillage system on soybean yield at ARDS Turda, International Symposium "Agrarian Economy and Rural Development - Realities and Perspectives for Romania" $8^{\text {th }}$ Edition, Bucharest, 16-17 November, p. 117123.

21. Stevanovic P, Popovic V, Filipović V, Terzić D, Rajičić V, Simić D, Tatić M, Tabaković M (2017). Influence of fertilization 
at the nitrogen content and mass of the nodule of soybean (Glycine max (L.) Merr). Journal of Institute of PKB Agroekonomik, Belgrade, 23(1-2): 119-128.

22. Vidican R, Rusu M, Rotar I, Mărghitaş M (2013). The manual of applying fertilizers, Risoprint ed., Cluj-Napoca.

23. *** MESP, 1987. Pedologic Studies Elaboration Metodology. Pedologic and Agrochemical Ins. Bucharest. Vol.1-3.
24. ***, PoliFact, 2015. ANOVA and Duncan's test pc program for variant analyses made for completely randomized poly-factorial experiences.

25. ***, SRTS, 2012. Romanian System of Soil Taxonomy. Ed. Estfalia, Bucharest

26. ${ }^{* * *}$, Meteorological Station Turda

27. ${ }^{* * *}$,https://www.donausoja.org/fileadmin/user_upload/ Partner_Agro_Info/Agriculture/Best_Practice_Manuals/ BPM_SOJA_RO.pdf 